\title{
Photosynthetic Symbionts of Aeschynomene spp. Form a Cluster with Bradyrhizobia on the Basis of Fatty Acid and rRNA Analyses
}

\author{
ROLANDO B. SO, ${ }^{1}$ JAGDISH K. LADHA, ${ }^{1 *}$ AND J. PETER W. YOUNG ${ }^{2}$ \\ Soil Microbiology, Division of Soil \& Water Sciences, The International Rice Research Institute, Manila, Philippines, ${ }^{1}$ \\ and Department of Biology, University of York, York YO1 5DD, United Kingdom ${ }^{2}$
}

\begin{abstract}
The relationship between photosynthetic rhizobia that nodulate 10 Aeschynomene species (Aeschynomene afraspera, Aeschynomene denticulata, Aeschynomene evenia, Aeschynomene indica, Aeschynomene nilotica, Aeschynomene pratensis, Aeschynomene rudis, Aeschynomene scabra, Aeschynomene schimperi, and Aeschynomene sensitiva) and reference strains of the genera Bradyrhizobium, Rhizobium, and Azorhizobium was investigated by analyzing cellular fatty acid methyl esters (FAME) and 16S rRNA sequences. The members of each genus produced very distinct FAME patterns, and the photosynthetic rhizobia formed a subcluster in the Bradyrhizobium cluster. The absence of the cyc $\mathrm{C}_{19: 0}$ type of fatty acid in all of the photosynthetic rhizobium strains isolated from 10 Aeschynomene species distinguished these microorganisms from other known rhizobia, including strain BTAi 1, a photosynthetic symbiont of $A$. indica. We sequenced a 264-base segment of the $16 \mathrm{~S}$ rRNA genes of selected strains after amplification by the PCR and compared the results with previously published sequences for species of rhizobia and related photosynthetic bacteria. Photosynthetic strains IRBG 2 (from $A$. afraspera), IRBG 230 (from $A$. nilotica), and ORS 322 (from $A$. afraspera) had identical sequences but were distinct from strain BTAi (from $A$. indica) and from strain IRBG 231 (from $A$. denticulata), which is similar to the type strain (DNA homology group Ia) of Bradyrhizobium japonicum. Nonphotosynthetic strain IRBG 274 (from $A$. afraspera) was closely related to Bradyrhizobium elkanii (DNA homology group II). All of the photosynthetic rhizobia clearly fell into the Bradyrhizobium cluster. Although the results of the FAME and 16S rRNA analyses were in excellent agreement, our placement of the photosynthetic rhizobia is in apparent conflict with phenotypic data, as determined by numerical taxonomy (Ladha and So, Int. J. Syst. Bacteriol., in press) which placed the photosynthetic rhizobia in a coherent cluster that is as far from the genus Bradyrhizobium as the genera Rhizobium and Azorhizobium are. While the FAME and 16S rRNA data probably provide a more reliable indication of phylogeny, the degree of phenotypic divergence observed raises questions concerning the polyphasic approach to bacterial systematics.
\end{abstract}

The root- and stem-nodulating bacterial symbionts of legumes are currently classified in three genera (the genera Rhizobium, Bradyrhizobium, and Azorhizobium), and the physiologically diverse relatives of these organisms belonging to the alpha subgroup of the Proteobacteria include photosynthetic anaerobes such as Rhodobacter and Rhodopseudomonas spp. $(39,40)$. Recently, the members of a group of symbiotic rhizobia isolated from stem nodules of Aeschynomene species have been shown to produce bacteriochlorophyll and to be capable of photosynthesis $(6,15)$. Solely on the basis of the presence of bacteriochlorophyll, Eaglesham et al. (6) suggested that strain BTAi 1 (isolated from Aeschynomene indica) might represent a new genus and proposed the name "Photorhizobium thompsonianum" (6). Subsequently, a study of part of the 16S rRNA sequence showed that strain BTAi 1 fell within the range of variation found in the genus Bradyrhizobium, as did the nonsymbiotic photosynthetic organism Rhodopseudomonas palustris (40).

Ladha and So (16) characterized 52 isolates obtained from nine Aeschynomene species that produce stem nodules and compared these isolates with 80 Bradyrhizobium, Rhizobium, and Azorhizobium strains. On the basis of the results of numerical taxonomy of 150 phenotypic traits, at least eight

\footnotetext{
* Corresponding author. Mailing address: Soil Microbiology, Division of Soil \& Water Sciences, The International Rice Research Institute, P.O. Box 933, Manila, Philippines. Phone: (63-2) 818-1926. Fax: (63-2) 818-2087. Electronic mail address: INTERNET: IN\% "JLADHA@CGNET.COM".
}

phena were distinguished. All of the photosynthetic rhizobia fell into a group that was well separated from other rhizobia. Although these results supported proposal that a new genus should be created for photosynthetic rhizobia, Ladha and So (16) stressed the need for additional tests before a final decision is made. The international subcommittee responsible for the taxonomy of rhizobia has recently recommended that proposals for new genera or species should be based on both phenotypic and phylogenetic traits (7). The study described in this paper was a continuation of our work on the characterization of rhizobia isolated from aquatic legumes belonging to the genera Sesbania and Aeschynomene. Representative strains of groups distinguished by phenotype-based numerical taxonomy were further characterized by fatty acid methyl ester (FAME) analysis and 16S rRNA sequencing. Comparisons of 16S rRNA sequences are now very widely used to determine phylogenetic relationships of bacteria $(35,36)$, and the significance of fatty acids in bacterial taxonomy has also been recognized (12). MacKenzie et al. (20) and Kuykendall et al. (13) have used fatty acid composition to determine similarities among strains of rhizobia. The objective of this work was to determine whether FAME and 16S rRNA sequence data support the conclusions of a previous numerical taxonomy study (16).

\section{MATERIALS AND METHODS}

Table 1 lists the sources and origins of 100 rhizobial strains used in this study. The strains were routinely maintained at the Soil Microbiology Section of The International Rice Research 
TABLE 1. Origins and hosts of bacterial strains used

\begin{tabular}{|c|c|c|c|c|c|c|c|}
\hline Genus & Cluster & Subcluster & Strain & Host & Nodule or strain origin & Source $^{a}$ & Reference no. \\
\hline \multirow[t]{64}{*}{ Bradyrhizobium } & I & IA & IRBG 231 & Aeschynomene denticulata & Laguna, Philippines & IRRI & 1 \\
\hline & I & IA & IRBG 284 & Aeschynomene pratensis & Iloilo, Philippines & IRRI & 2 \\
\hline & I & IA & IRBG 287 & Aeschynomene pratensis & Laguna, Philippines & IRRI & 3 \\
\hline & I & IA & IRBG 114 & Aeschynomene sensitiva & Laguna, Philippines & IRRI & 4 \\
\hline & I & IA & IRBG 115 & Aeschynomene sensitiva & Laguna, Philippines & IRRI & 5 \\
\hline & I & IA & IRBG 122 & Aeschynomene sensitiva & Iloilo, Philippines & IRRI & 6 \\
\hline & I & IA & IRBG 2 & Aeschynomene afraspera & Laguna, Philippines & IRRI & 7 \\
\hline & I & IA & IRBG 79 & Aeschynomene afraspera & Laguna, Philippines & IRRI & 8 \\
\hline & I & IA & IRBG 81 & Aeschynomene afraspera & Laguna, Philippines & IRRI & 9 \\
\hline & I & IA & IRBG 124 & Aeschynomene pratensis & Laguna, Philippines & IRRI & 10 \\
\hline & I & IA & IRBG 126 & Aeschynomene pratensis & Iloilo, Philippines & IRRI & 11 \\
\hline & I & IA & IRBG 119 & Aeschynomene sensitiva & Laguna, Philippines & IRRI & 12 \\
\hline & I & IA & IRBG 92 & Aeschynomene indica & Laguna, Philippines & IRRI & 13 \\
\hline & I & IA & IRBG 91 & Aeschynomene indica & Laguna, Philippines & IRRI & 14 \\
\hline & I & IA & IRBG 348 & Aeschynomene indica & Laguna, Philippines & IRRI & 15 \\
\hline & I & IA & IRBG 125 & Aeschynomene pratensis & Laguna, Philippines & IRRI & 16 \\
\hline & I & IA & IRBG 127 & Aeschynomene pratensis & Iloilo, Philippines & IRRI & 17 \\
\hline & I & IA & IRBG 297 & Aeschynomene sensitiva & Iloilo, Philippines & IRRI & 18 \\
\hline & I & IA & IRBG 123 & Aeschynomene pratensis & Iloilo, Philippines & IRRI & 19 \\
\hline & I & IA & IRBG 250 & Aeschynomene schimperi & Laguna, Philippines & IRRI & 20 \\
\hline & I & IA & IRBG 234 & Aeschynomene evenia & Laguna, Philippines & IRRI & 21 \\
\hline & I & IA & IRBG 233 & Aeschynomene evenia & Laguna, Philippines & IRRI & 22 \\
\hline & I & IA & IRBG 229 & Aeschynomene evenia & Laguna, Philippines & IRRI & 23 \\
\hline & I & IA & IRBG 238 & Aeschynomene rudis & Laguna, Philippines & IRRI & 24 \\
\hline & I & IA & IRBG 83 & Aeschynomene afraspera & Laguna, Philippines & IRRI & 25 \\
\hline & I & IA & ORS 322 & Aeschynomene afraspera & Senegal & ORSTOM & 26 \\
\hline & I & IA & IRBG 228 & Aeschynomene pratensis & Laguna, Philippines & IRRI & 27 \\
\hline & I & IA & IRBG 210 & Aeschynomene indica & Iloilo, Philippines & IRRI & 28 \\
\hline & I & IA & IRBG 224 & Aeschynomene indica & Iloilo, Philippines & IRRI & 29 \\
\hline & I & IA & IRBG 67 & Aeschynomene scabra & Laguna, Philippines & IRRI & 30 \\
\hline & I & IA & IRBG 230 & Aeschynomene nilotica & Laguna, Philippines & IRRI & 31 \\
\hline & I & IA & IRBG 118 & Aeschynomene sensitiva & Laguna, Philippines & IRRI & 32 \\
\hline & I & IA & IRBG 296 & Aeschynomene sensitiva & Iloilo, Philippines & IRRI & 33 \\
\hline & I & IA & IRBG 294 & Aeschynomene sensitiva & Iloilo, Philippines & IRRI & 34 \\
\hline & I & IB & A1017 & Glycine $\max$ & Japan & IB & 35 \\
\hline & I & IB & IRBG 271 & Aeschynomene fluminensis & Laguna, Philippines & IRRI & 36 \\
\hline & I & IB & IRBG 272 & Aeschynomene fluminensis & Laguna, Philippines & IRRI & 37 \\
\hline & I & IB & USDA 110 & Glycine $\max$ & United States? & USDA & 38 \\
\hline & I & IB & IRBG 301 & Aeschynomene fluminensis & Laguna, Philippines & IRRI & 39 \\
\hline & I & IB & NIAES 3316 & Glycine $\max$ & Japan & IB & 40 \\
\hline & I & IB & IRBG 270 & Aeschynomene fluminensis & Laguna, Philippines & IRRI & 41 \\
\hline & I & IB & TAL 835 & Macrotyloma africanum & Zimbabwe & NifTAL & 42 \\
\hline & I & IB & LB 5 & Acacia manguim & Philippines & BIOTECH & 43 \\
\hline & I & IB & LB 6 & Acacia manguim & Philippines & BIOTECH & 44 \\
\hline & I & IB & TAL 1521 & Acacia manguim & Hawaii & NifTAL & 45 \\
\hline & I & IB & TAL 289 & Indigofera endecaphylla & Hawaii & NifTAL & 46 \\
\hline & I & IB & TAL 760 & Indigofera hirsuta & Mexico & NifTAL & 47 \\
\hline & I & IB & TAL 761 & Indigofera hirsuta & Mexico & NifTAL & 48 \\
\hline & I & IB & TAL 290 & Indigofera suffruticosa & Hawaii & NifTAL & 49 \\
\hline & I & IB & TAL 350 & Indigofera suffruticosa & Hawaii & NifTAL & 50 \\
\hline & I & IB & TAL 169 & Vigna unguiculata & Wisconsin & NifTAL & 51 \\
\hline & I & IB & TAL 1038 & Indigofera sp. & Kenya & NifTAL & 52 \\
\hline & I & IB & IRBG 309 & Crotalaria juncea & India & IRRI & 53 \\
\hline & I & IB & TAL 209 & Vigna radiata & Thailand & NifTAL & 54 \\
\hline & I & IB & BTAi 1 & Aeschynomene indica & United States & BTI & 55 \\
\hline & I & IC & IRBG 251 & Aeschynomene afraspera & Thailand & IRRI & 56 \\
\hline & I & IC & IRBG 274 & Aeschynomene afraspera & Thailand & IRRI & 57 \\
\hline & I & IC & USDA 31 & Glycine $\max$ & United States? & USDA & 58 \\
\hline & I & IC & USDA $76^{T}$ & Glycine $\max$ & United States? & USDA & 59 \\
\hline & I & IC & IRBG 342 & Glycine $\max$ & Laguna, Philippines & IRRI & 60 \\
\hline & I & IC & IRBG 343 & Glycine $\max$ & Laguna, Philippines & IRRI & 61 \\
\hline & I & IC & J501 & Glycine $\max$ & Japan & IB & 62 \\
\hline & I & IC & JIR 33 & Glycine $\max$ & Japan & IB & 63 \\
\hline & I & IC & TAL 1037 & Indigofera brevicalyx & Kenya & NifTAL & 64 \\
\hline \multirow[t]{4}{*}{ Rhizobium } & II & IIA & IRBG 350 & Neptunia oleracea & Maahas, Philippines & IRRI & 65 \\
\hline & II & IIA & RG $504^{\mathrm{T}}$ & Galega officinalis & New Zealand & NZP & 66 \\
\hline & II & IIB & TAL 1436 & Acacia famesiana & Senegal & NifTAL & 67 \\
\hline & II & IIB & IC 3100 & Cajanus cajan & India & ICRISAT & 68 \\
\hline
\end{tabular}


TABLE $1-$ Continued

\begin{tabular}{|c|c|c|c|c|c|c|c|}
\hline Genus & Cluster & Subcluster & Strain & Host & Nodule or strain origin & Source & Reference no \\
\hline & II & IIB & TAL 20 & Cajanus cajan & Hawaii & NifTAL & 69 \\
\hline & II & IIB & TAL 1113 & Sesbania $\mathrm{sp}$ & India & NifTAL & 70 \\
\hline & II & IIB & TAL 1115 & Sesbania sp. & India & NifTAL & 71 \\
\hline & II & IIB & NZP 4017 & Medicago sativa & New Zealand & NZP & 72 \\
\hline & II & IIB & TAL 380 & Medicago sativa & New South Wales, Australia & NifTAL & 73 \\
\hline & II & IIB & TAL 1372 & Medicago sativa & Brazil & NifTAL & 74 \\
\hline & II & IIB & USDA $205^{\mathrm{T}}$ & Glycine sojae & People's Republic of China & USDA & 75 \\
\hline & II & IIB & TAL 638 & Lens culinaris & Hawaii & NifTAL & 76 \\
\hline & II & IIB & TAL 1383 & Phaseolus vulgaris & Guatemala & NifTAL & 77 \\
\hline & II & IIB & TAL 382 & Trifolium semipilosum & Australia & NifTAL & 78 \\
\hline & II & IIB & RL 8002 & Phaseolus vulgaris & United Kingdom & JII & 79 \\
\hline & II & IIB & TAL 182 & Phaseolus vulgaris & Hawaii & NifTAL & 80 \\
\hline & II & IIB & TAL 674 & Sesbania rostrata & Hawaii & NifTAL & 81 \\
\hline & II & IIB & TAL 1123 & Sesbania macrocarpa & Missouri & NifTAL & 82 \\
\hline & II & IIB & TAL 1797 & Phaseolus vulgaris & United States & NifTAL & 83 \\
\hline & II & IIB & TAL 634 & Lathyrus hirsutus & Missouri & NifTAL & 84 \\
\hline & II & IIIB & TAL 1298 & Galega orientalis & Texas & NifTAL & 85 \\
\hline & II & IIB & TAL 1768 & Gliciridia sepium & Mexico & NifTAL & 86 \\
\hline \multirow[t]{14}{*}{ Azorhizobium } & III & & IRBG 32 & Sesbania rostrata & Cotabato, Philippines & IRRI & 87 \\
\hline & III & & IRBG 320 & Sesbania rostrata & Maahas, Philippines & IRRI & 88 \\
\hline & III & & IRBG 313 & Sesbania rostrata & India & IRRI & 89 \\
\hline & III & & IRBG 317 & Sesbania rostrata & India & IRRI & 90 \\
\hline & III & & IRBG 314 & Sesbania rostrata & India & IRRI & 91 \\
\hline & III & & IRBG 316 & Sesbania rostrata & India & IRRI & 92 \\
\hline & III & & IRBG 315 & Sesbania rostrata & India & IRRI & 93 \\
\hline & III & & IRBG 319 & Sesbania rostrata & Maahas, Philippines & IRRI & 94 \\
\hline & III & & IRBG 318 & Sesbania rostrata & Maahas, Philippines & IRRI & 95 \\
\hline & III & & IRBG 44 & Sesbania rostrata & Tiaong, Philippines & IRRI & 96 \\
\hline & III & & ORS $571^{\mathrm{T}}$ & Sesbania rostrata & Senegal & ORSTOM & 97 \\
\hline & III & & IRBG 9 & Sesbania rostrata & Maahas, Philippines & IRRI & 98 \\
\hline & III & & IRBG 21 & Sesbania rostrata & Maligaya, Philippines & IRRI & 99 \\
\hline & III & & IRBG 45 & Sesbania rostrata & Tiaong, Philippines & IRRI & 100 \\
\hline
\end{tabular}

${ }^{a}$ BIOTECH, National Institutes of Applied Microbiology and Biotechnology, University of the Philippines at Los Baños, Los Baños, Philippines; BTI, Boyce Thompson Research Institute, New York, N.Y.; IB, Ibaraki University Department of Agricultural Chemistry, Ibaraki, Japan; ICRISAT, International Centre for Research in Semi-Arid Tropics, Patancheru, India; IRBG, The International Rice Research Institute Bacterial Germplasm, IRRI, Manila, Philippines; JII, John Innes Institute, Norwich, United Kingdom; NifTAL, Nitrogen Fixation in Tropical Agricultural Legumes, University of Hawaii, Paia, Hawaii; NZP, Culture Collection of the Department for Scientific and Industrial Research, Palmerston North, New Zealand; ORSTOM, Institut Francais de Recherche Scientifique Pour le Developpement en Cooperation, Paris, France; USDA, U.S. Department of Agriculture, Beltsville, Md. T = type strain.

Institute (IRRI) as part of the Biofertilizer Germplasm Collection (30). Most of the strains were characterized in a previous study in which numerous cultural and phenotypic characteristics were determined (16).

Cultural conditions. Mannitol-yeast extract medium was the routine medium used for isolation, purification, and maintenance of rhizobia (16). The photosynthetic rhizobia grew better in a glucose-based medium than in the mannitol-based mannitol-yeast extract medium in which organisms were initially isolated from Aeschynomene nodules. Although growth medium has been shown to affect FAME profiles in certain cases (24), preliminary studies showed that the FAME profiles of the photosynthetic bacteria were not significantly different when the organisms were grown in glucose- and mannitol- based media (Table 2). Hence, glucose-yeast extract medium was used to grow photosynthetic rhizobia and mannitol-yeast extract medium was used to grow nonphotosynthetic rhizobia throughout this study.

FAME analyses. Freeze-dried bacterial cells (approximately $20 \mathrm{mg}$ ) were methanolyzed with $2 \mathrm{M} \mathrm{HCl}$ in $5 \%$ methanol as previously described (31). The FAME fraction was obtained by extracting the preparation three times with petroleum benzine and then washing the preparation with an equal volume of distilled water. After the solvent phase was separated, it was dried under a stream of nitrogen and redissolved in petroleum benzine. The extract was divided into two portions; the first portion was used to determine the total FAME content, and the second portion was spotted onto a thin-layer chromatog-

TABLE 2. Effects of carbon sources on the FAME compositions of photosynthetic rhizobia

\begin{tabular}{lcccccccccc}
\hline \multirow{2}{*}{$\begin{array}{c}\text { Carbon } \\
\text { source }\end{array}$} & \multicolumn{10}{c}{ Fatty acid composition (\% of total peak area) ${ }^{a}$} \\
\cline { 2 - 9 } & $\mathrm{C}_{10: 0}$ & $\mathrm{C}_{12: 0}$ & $\mathrm{C}_{14: 1}$ & $\mathrm{C}_{16: 0}$ & $\mathrm{C}_{16: 1}$ & $\mathrm{C}_{17: 0}$ & $\mathrm{C}_{18: 0}$ & $\mathrm{C}_{18: 1}$ & $\mathrm{C}_{18: 1^{b}}$ & $\mathrm{cyc} \mathrm{C}_{19}{ }^{c}$ \\
\hline Glucose & $0.8 \pm 0.46$ & $0.1 \pm 0.15$ & $0.2 \pm 0.16$ & $18.7 \pm 1.46$ & $0.6 \pm 0.54$ & $0.1 \pm 0.07$ & $0.7 \pm 0.92$ & $3.2 \pm 2.22$ & $72.9 \pm 6.23$ & $3.9 \pm 1.21$ \\
Mannitol & $0.8 \pm 1.48$ & $0.3 \pm 0.21$ & $0.2 \pm 0.39$ & $19.1 \pm 7.55$ & $0.5 \pm 0.49$ & $0.1 \pm 0.08$ & $1.1 \pm 1.45$ & $2.0 \pm 1.92$ & $74.2 \pm 8.25$ & $2.3 \pm 1.03$
\end{tabular}

a The values are means \pm standard deviations for two or three determinations. The strains used were strains IRBG 114, IRBG 115 , IRBG 122 , IRBG 125, IRBG 127, BTAi 1, and ORS 322. The nutrient compositions of the culture media were the same except for the carbon sources (see Materials and Methods).

${ }^{b}$ cis-9-Octadecenoate (cis-vaccinic acid).

${ }^{c}$ cyc $\mathrm{C}_{19: 0}$ was found only in strain BTAi 1 . 
raphy plate (precoated Silica Gel 60; Merck) to separate the polar and nonpolar FAMEs. The plates were developed in an elution tank by using hexane-diethyl ether (90:10, vol/vol) as the mobile phase. The extracts were visualized with UV light and then were eluted with diethyl ether, evaporated to dryness, and redissolved in $100 \mu \mathrm{l}$ of diethyl ether.

The FAMEs were analyzed with a Hitachi model 263-30 gas chromatograph equipped with a flame ionization detector. The following two types of columns were used: $5 \%$ DEGS-PS in Supelcoport 100/200 and 3\% SP $2100 \mathrm{DOH}$ in Supelcoport $100 / 200$. The injection and detector temperatures were $250^{\circ} \mathrm{C}$. Isothermal and gradient temperature profiles were used for each analysis. The oven temperatures used for isothermal conditions were $190^{\circ} \mathrm{C}$ for nonpolar column types and $210^{\circ} \mathrm{C}$ for polar column types. For temperature gradients, the oven temperature was programmed to increase from 150 to $250^{\circ} \mathrm{C}$ at a ramp rate of $15^{\circ} \mathrm{C} \cdot \mathrm{min}^{-1}$. Nitrogen was used as the carrier gas at flow rates of 40 and $20 \mathrm{ml}^{-1} \mathrm{~min}^{-1}$ for isothermal conditions and temperature gradients, respectively. FAMEs were identified by comparing their retention times with the retention times of known authentic standards and computing the equivalent chain lengths. The identities of some FAMEs were confirmed by gas chromatography-mass spectrometry, using a Hewlett-Packard model 5985 gas chromatographymass spectrometer, an ionizing energy of $70 \mathrm{eV}$, and a type DB-1 fused silica column, which was subjected to the following temperature program: $50^{\circ} \mathrm{C}$ for $1 \mathrm{~min}$, increased at a rate of $30^{\circ} \mathrm{C} \cdot \mathrm{min}^{-1}$ until the temperature was $270^{\circ} \mathrm{C}$, and $270^{\circ} \mathrm{C}$ for $15 \mathrm{~min}$. The gas chromatography-mass spectrometry analyses were carried out by using helium as the carrier gas.

16S rRNA PCR amplification and sequencing. The sequences of portions of the 16S rRNA genes of photosynthetic rhizobial strains IRBG 2, IRBG 230, IRBG 231, and ORS 322 and nonphotosynthetic strains IRBG 274 and IRBG 309 were determined after PCR amplification. The sequences corresponding to nucleotides 44 to 377 in the Escherichia coli 16S rRNA sequence (2) were amplified with forward primer Y1 (5'-TGGCTCAGAACGAACGCTGGCGGC-3') and reverse primer Y2 (5'-CCCACTGCTGCCTCCCGTAGGAGT-3'), essentially as described by Young et al. (40). DNA amplicons were $312 \mathrm{bp}$ long and were purified by using Qiagen anion-exchange columns (Diagen GmbH, Dusseldorf, Germany). Purified DNA products were sequenced by using the amplifying primers and a T7 sequencing kit (Pharmacia LKB), which yielded sequence information for 264 bases between the primers. Up to 10 bases at the beginning and up to 20 bases at the end were unreadable for certain strains, but an examination of previously published sequences showed that these regions normally provide little useful information.

Data analyses. The peak areas of individual FAMEs were expressed as relative peak percentages, which were determined by dividing the area of each FAME by the total peak area of all FAMEs. The means, minimums, maximums, and standard deviations were derived from the relative peak percentage values. The mean FAME values used for each strain were derived from replicate values from two or three analyses and were used in the multivariate statistical analyses. Levels of similarity were calculated by using Euclidean distance coefficients derived from the standardized FAME values. Hierarchical clustering was performed by using the mean linkage method (28).

Sequence data for $16 \mathrm{~S}$ rRNAs were aligned by using the Wisconsin programs (4) and were compared with previously published sequence data for Azorhizobium, Bradyrhizobium, and Rhizobium spp. and photosynthetic bacteria (9, 34, 40). The computer programs used to analyze $16 \mathrm{~S}$ rRNA data were
NTSYS-pc (Applied Biostatistics, Inc.) and SIMGEND (similarity for genetic data using the Jukes-Cantor method [11]), and a dendrogram was generated by using the NJOIN program (neighbor-joining method of Saitou and Nei [27]). Only positions represented by a known nucleotide in each of the sequences in the alignment were considered in the analysis.

Nucleotide sequence accession numbers. The GenBank accession numbers for the 16S rRNA sequences of some of the organisms included in this study are as follows: IRBG 2, U04715; IRBG 230, U04719; IRBG 231, U04720; IRBG 274, U04718; IRBG 309, U04717; ORS 322, U04716; BTAi 1, M55492; and B. elkanii USDA $76^{\mathrm{T}}$, M55490.

\section{RESULTS}

FAMEs and carbon sources. The use of glucose or mannitol as the carbon source in the culture medium did not affect the FAME profiles of the photosynthetic rhizobia (Table 2). The relative levels of cyc $\mathrm{C}_{19: 0}$, a FAME unique to strain BTAi 1 (Fig. 1), also were not affected.

FAME analyses. On the basis of cellular FAME profiles, the 100 rhizobial strains which we studied fell very clearly into three clusters corresponding to the three currently recognized genera, Bradyrhizobium (cluster I), Rhizobium (cluster II), and Azorhizobium (cluster III) (Fig. 2 and Table 1). The photosynthetic rhizobia fell into cluster I together with the bradyrhizobia. Subcluster IA contained only photosynthetic rhizobia and included all of the photosynthetic rhizobia except BTAi 1, which fell into subcluster IB. Subcluster IB also contained the nonphotosynthetic rhizobial strains isolated from Aeschynomene fluminensis (IRBG 270, IRBG 271, IRBG 272, and IRBG 301) and strains isolated from a number of other hosts, including Acacia mangium (LB5, LB6, and TAL 1521), Crotalaria juncea (IRBG 309), Glycine max (USDA 110, A1017, and NIAES 3316), Indigofera endecaphylla (TAL 289), Indigofera hirsuta (TAL 760 and TAL 761), Indigofera suffruticosa (TAL 290 and TAL 350), Indigofera sp. (TAL 1038), Macrotyloma africanum (TAL 835), Vigna radiata (TAL 209), and Vigna unguiculata (TAL 169). Strain BTAil could be differentiated from the other photosynthetic rhizobia by the presence of cyc $\mathrm{C}_{19: 0}$ and by differences in the amounts of $\mathrm{C}_{18: 0}$ and $\mathrm{C}_{18: 1}$ FAMEs. A third subcluster, subcluster IC, contained the two nonphotosynthetic rhizobial strains isolated from Aeschynomene afraspera (IRBG 251 and IRBG 274), a strain isolated from Indigofera brevicalyx (TAL 1037), and six strains symbiotic on Glycine max (IRBG 342, IRBG 343, J501, JIR 33, USDA 31 , and USDA $76^{\mathrm{T}}$ [T = type strain]). The latter strains included the type strain of Bradyrhizobium elkanii, strain USDA 76.

On the basis of FAME profiles, of all of the fast-growing rhizobia formed cluster II. Two strains, which were isolated from Galega officinalis and Neptunia oleracea, formed a very distinct subcluster (subcluster IIA), while 20 strains isolated from several legumes (Acacia farnesiana, Cajanus cajan, Galega orientalis, Gliciridia sepium, Glycine sojae, Lens culinaris, Lathyrus hirsutus, Medicago sativa, Phaseolus vulgaris, Sesbania macrocarpa, Sesbania rostrata, Sesbania sp., and Trifolium semipilosum) made up subcluster IB.

All of the stem- and root-nodulating azorhizobia (eight strains from The Philippines, five strains from India, and one strain from Senegal) formed another homogeneous cluster, cluster III. The azorhizobia could be distinguished from the stem- and root-nodulating photosynthetic rhizobia by differences in the amounts of some types of FAMEs, namely, cyc $\mathrm{C}_{19: 0}, \mathrm{C}_{16: 0}, \mathrm{C}_{18: 0}$, and 3-OH $\mathrm{C}_{14: 0}$ (Table 3).

16S rRNA sequence analysis. Figure 3 shows the sequences 

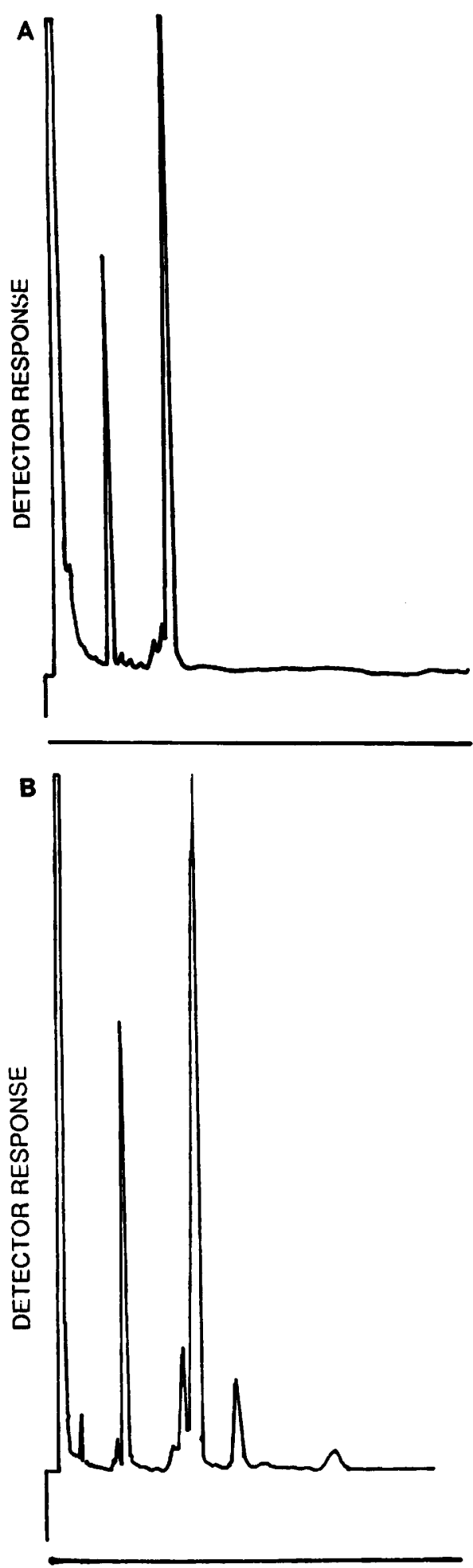

FIG. 1. Chromatograms of FAME profiles for photosynthetic rhizobium strain IRBG 2 (from Aeschynomene afraspera) (A) and strain BTAi 1 (from Aeschynomene indica) (B). of the 16S rRNA gene fragments for several photosynthetic rhizobium strains isolated from Aeschynomene spp. (IRBG 2, IRBG 230, IRBG 231, and ORS 322), nonphotosynthetic Aeschynomene rhizobium strain IRBG 274, and Bradyrhizobium sp. strain IRBG 309 (isolated from Crotalaria sp.), along with previously published sequences for comparison. Three of the photosynthetic rhizobia (IRBG 2, IRBG 230, and ORS 322) had identical sequences, but these organisms differed at two or three nucleotide sites from two other photosynthetic rhizobia, IRBG 231 and BTAi 1, and by up to six nucleotides from the most dissimilar bradyrhizobia (Table 4). On the other hand, all of the photosynthetic rhizobia differed at more than 20 nucleotide sites from Rhizobium and Azorhizobium spp. The phylogenetic tree in Fig. 4 was obtained by using the neighborjoining method (27) of the Jukes-Cantor distance matrix for partial 16S rRNA sequences (Table 4). This tree is in good agreement with a previously described phylogeny for the alpha subgroup of the Proteobacteria (35). All of the photosynthetic bacteria were found on the Bradyrhizobium-Rhodopseudomonas palustris branch.

\section{DISCUSSION}

The FAME analysis in this study provided very clear discrimination of the genera Rhizobium, Bradyrhizobium, and Azorhizobium. MacKenzie et al. (20) obtained clear separation of the genera Rhizobium and Bradyrhizobium on the basis of FAME profiles, but were not able to distinguish additional groups at a lower level. Kuykendall et al. (13), using capillary column chromatography, were able to subdivide soybean Bradyrhizobium strains and found that their FAME groups correlated with the DNA homology groups of Hollis et al. (8). These authors argued that MacKenzie et al. (20) may have been unable to separate strains at the subgeneric level because they used packed-column chromatography. However, in this study we used packed-column chromatography but distinguished clear subgeneric groups. In our study we included a large number of strains and used a numerical statistical approach.

On the basis of FAME profiles, the Aeschynomene rhizobia exhibited much closer affinity with the Bradyrhizobium group (cluster I) than with the Rhizobium group (cluster II). The absence of cyc $\mathrm{C}_{19: 0}$ in all of the photosynthetic rhizobium strains (except BTAi 1) (Fig. 1) separated our strains from the nonphotosynthetic rhizobium strains belonging to all three currently recognized genera (Fig. 2). On the other hand, the 3-hydroxy type of FAME, which has been reported to be a characteristic of gram-negative bacteria (12), was found in Rhizobium and Azorhizobium spp. (this study) but not in photosynthetic rhizobium strains or Bradyrhizobium strains (Table 3).

In the Rhizobium cluster, the relationships suggested by the results of the FAME comparisons are very similar to the relationships established by other methods. Two examples should serve to illustrate this. The FAME profile of Rhizobium fredii USDA $205^{\mathrm{T}}$ is very similar to the FAME profiles of Rhizobium meliloti NZP 4017, TAL 380, and TAL 1372. This finding is consistent with previously published DNA-DNA hybridization data (33), DNA-rRNA hybridization data (10), serological test data (28), and $16 \mathrm{~S}$ rRNA sequence data (9) and further supports the hypothesis that Rhizobium fredii belongs to the genus Rhizobium (9) and does not require a new genus, Sinorhizobium, as has been proposed by Chen et al. (3). Second, Rhizobium galegae RG 504, together with an isolate obtained from Neptunia sp., had a FAME profile that placed it well outside subcluster IIB, which included representatives of the species Rhizobium leguminosarum, Rhizobium meliloti, and 


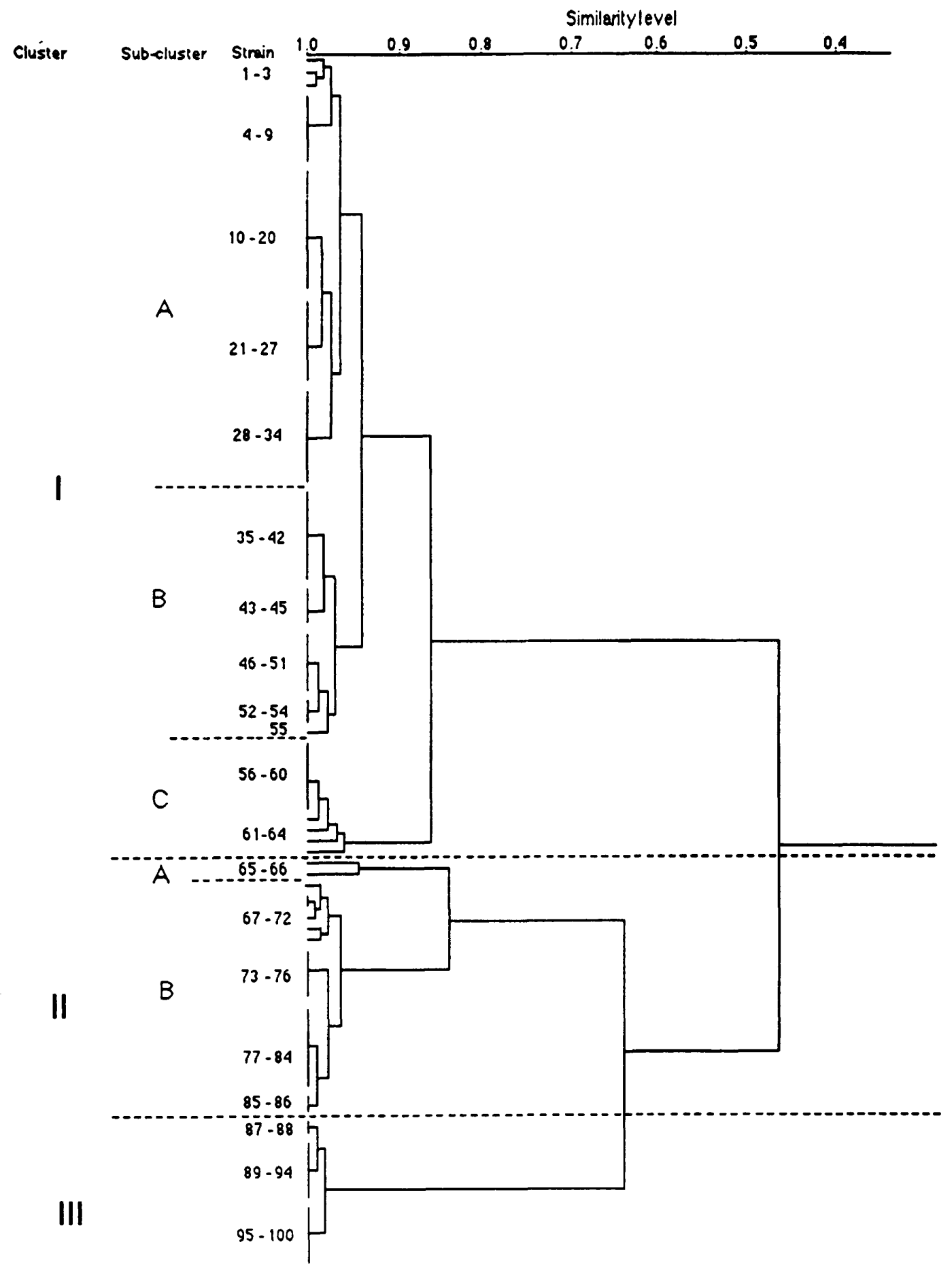

FIG. 2. Dendrogram showing the relationship between the FAME profiles of photosynthetic Aeschynomene rhizobia and the FAME profiles of Bradyrhizobium strains (cluster I), Rhizobium strains (cluster II), and Azorhizobium strains (cluster III), determined by using mean average linkage data. Subcluster IA comprises all of the photosynthetic rhizobia, while subclusters IB and IC contain all of the nonphotosynthetic rhizobia except strain BTAi 1, which is in subcluster IB (reference no. 55 [Table 1]).

Rhizobium fredii. This is entirely consistent with the 16S rRNA sequence data $(34,37)$, which indicated that Rhizobium galegae is a rather distantly related member of the genus, and with data from previous studies of Rhizobium galegae in which DNADNA hybridization, phage typing, cross-inoculation, and phenotypic traits were examined (17-19).
The FAME profiles of the strains in cluster III, which included 14 strains of azorhizobia from three countries, were homogeneous. Our data further confirmed the distinctness of the genus Azorhizobium (5). However, strain TAL 674, which was described as an isolate obtained from $S$. rostrata, fell into the Rhizobium cluster. Furthermore, we failed to induce stem 
TABLE 3. FAME profiles of photosynthetic rhizobia and the genera Rhizobium, Bradyrhizobium, and Azorhizobium

\begin{tabular}{|c|c|c|c|c|c|c|c|c|c|c|c|c|c|c|c|c|c|c|c|c|c|c|c|}
\hline \multirow[b]{2}{*}{ Cluster } & \multirow{2}{*}{$\begin{array}{l}\text { Sub- } \\
\text { cluster }\end{array}$} & \multirow{2}{*}{ Parameter $^{a}$} & \multicolumn{21}{|c|}{ Fatty acid composition ( $\%$ of total peak area) ${ }^{b}$} \\
\hline & & & $\mathrm{C}_{10: 0}$ & $\mathrm{C}_{12: 0}$ & $C_{13: 0}$ & $\mathrm{C}_{13: 1}$ & $\mathrm{C}_{14: 0}$ & $\mathrm{C}_{14: 1}$ & $\mathrm{C}_{15: 0}$ & $\mathrm{C}_{15: 1}$ & $\mathrm{C}_{16: 0}$ & $\mathrm{C}_{16: 1}$ & $\mathrm{C}_{17: 0}$ & $C_{17: 0}$ & $\mathrm{C}_{18: 0}$ & $\mathrm{C}_{18: 1}$ & $\mathrm{C}_{18: 1}{ }^{*}$ & $C_{19: 0 .}$ & $C_{19: 0}$ & $\begin{array}{r}3-\mathrm{OH} \\
\mathrm{C}_{14: 0}\end{array}$ & $\mathrm{X} 1$ & $\mathrm{X} 2$ & $\mathrm{X} 3$ \\
\hline \multirow[t]{12}{*}{ I } & \multirow[t]{4}{*}{ IA } & Minimum & 0.00 & 0.00 & 0.00 & 0.00 & 0.00 & 0.00 & 0.00 & 0.00 & 14.57 & 0.05 & 0.00 & 0.00 & 0.00 & 0.80 & 70.59 & 0.00 & 0.00 & 0.00 & 0.00 & 0.00 & 0.00 \\
\hline & & Maximum & 0.33 & 0.68 & 0.00 & 0.00 & 0.93 & 0.00 & 0.00 & 0.21 & 21.52 & 1.34 & 0.47 & 0.85 & 0.85 & 7.41 & 82.44 & 0.00 & 0.00 & 0.00 & 0.00 & 0.00 & 0.00 \\
\hline & & Mean & 0.02 & 0.23 & 0.01 & 0.00 & 0.14 & 0.00 & 0.05 & 0.02 & 17.18 & 0.59 & 0.15 & 0.12 & 0.58 & 4.14 & 76.45 & 0.00 & 0.00 & 0.00 & 0.00 & 0.00 & 0.00 \\
\hline & & SD & 0.11 & 0.37 & 0.01 & 0.00 & 0.25 & 0.00 & 0.04 & 0.07 & 3.11 & 0.38 & 0.24 & 0.34 & 0.72 & 2.46 & 4.60 & 0.00 & 0.00 & 0.00 & 0.00 & 0.00 & 0.00 \\
\hline & \multirow[t]{4}{*}{ IB } & Minimum & 0.00 & 0.00 & 0.00 & 0.00 & 0.06 & 0.00 & 0.00 & 0.00 & 3.11 & 0.06 & 0.00 & 0.00 & 1.02 & 0.00 & 4.60 & 0.00 & 0.12 & 0.00 & 0.00 & 0.00 & 0.00 \\
\hline & & Maximum & 0.11 & 0.93 & 0.00 & 0.00 & 0.30 & 0.07 & 0.15 & 0.35 & 20.54 & 2.40 & 0.69 & 0.97 & 9.05 & 2.46 & 80.79 & 0.07 & 7.80 & 0.00 & 0.00 & 0.00 & 1.50 \\
\hline & & Mean & 0.00 & 0.16 & 0.00 & 0.00 & 0.18 & 0.02 & 0.01 & 0.05 & 16.76 & 0.78 & 0.24 & 0.17 & 2.33 & 0.36 & 76.60 & 0.01 & 3.10 & 0.00 & 0.00 & 0.00 & 0.45 \\
\hline & & SD & 0.05 & 0.31 & 0.00 & 0.00 & 0.12 & 0.02 & 0.05 & 0.11 & 2.62 & 0.75 & 0.29 & 0.32 & 2.89 & 0.45 & 4.09 & 0.02 & 2.40 & 0.00 & 0.00 & 0.00 & 0.67 \\
\hline & \multirow[t]{4}{*}{ IC } & Minimum & 0.00 & 0.00 & 0.00 & 0.00 & 0.00 & 0.00 & 0.00 & 0.00 & 17.80 & 0.20 & 0.00 & 0.00 & 0.26 & 0.00 & 46.00 & 0.00 & 0.20 & 0.00 & 0.00 & 0.00 & 0.00 \\
\hline & & Maximum & 0.89 & 1.62 & 0.95 & 0.34 & 1.07 & 0.00 & 0.44 & 0.96 & 25.20 & 4.60 & 2.08 & 0.37 & 2.60 & 12.99 & 74.94 & 0.10 & 23.29 & 0.00 & 0.00 & 0.05 & 7.94 \\
\hline & & Mean & 0.30 & 0.15 & 0.36 & 0.01 & 0.27 & 0.00 & 0.09 & 0.22 & 20.54 & 0.81 & 0.72 & 0.10 & 1.35 & 3.44 & 59.62 & 0.02 & 11.06 & 0.00 & 0.16 & 0.00 & 1.79 \\
\hline & & SD & 0.28 & 0.46 & 0.69 & 0.11 & 0.37 & 0.00 & 0.14 & 0.33 & 2.27 & 1.33 & 1.54 & 0.13 & 0.87 & 4.42 & 8.46 & 0.03 & 7.86 & 0.00 & 0.64 & 0.01 & 2.43 \\
\hline \multirow[t]{8}{*}{ II } & \multirow[t]{4}{*}{ IIA } & Minimum & 0.00 & 0.00 & 0.00 & 0.00 & 0.00 & 0.00 & 0.00 & 0.00 & 2.27 & 1.20 & 0.00 & 0.00 & 0.26 & 0.00 & 8.46 & 0.00 & 0.20 & 0.00 & 0.00 & 0.00 & 0.00 \\
\hline & & Maximum & 0.89 & 1.62 & 0.95 & 0.34 & 1.07 & 0.00 & 0.44 & 0.96 & 25.20 & 4.60 & 2.08 & 0.37 & 14.20 & 12.99 & 74.94 & 0.10 & 28.30 & 8.82 & 0.64 & 0.05 & 7.94 \\
\hline & & Mean & 0.17 & 0.00 & 0.31 & 0.06 & 0.27 & 0.00 & 0.00 & 0.00 & 16.75 & 3.47 & 1.02 & 0.03 & 12.38 & 4.38 & 26.98 & 0.01 & 26.25 & 5.29 & 0.00 & 0.00 & 3.14 \\
\hline & & SD & 0.19 & 0.00 & 0.36 & 0.06 & 0.21 & 0.00 & 0.00 & 0.00 & 3.08 & 2.49 & 0.01 & 0.05 & 1.26 & 3.12 & 4.45 & 0.00 & 4.63 & 4.25 & 0.00 & 0.00 & 3.46 \\
\hline & \multirow[t]{4}{*}{ IIB } & Minimum & 0.00 & 0.00 & 0.00 & 0.00 & 0.00 & 0.00 & 0.00 & 0.00 & 10.72 & 0.26 & 0.00 & 0.18 & 1.14 & 0.52 & 31.74 & 0.00 & 11.05 & 3.55 & 0.00 & 0.80 & 2.05 \\
\hline & & Maximum & 0.00 & 0.96 & 0.00 & 0.00 & 1.00 & 0.00 & 0.08 & 0.00 & 16.05 & 4.41 & 0.32 & 3.07 & 6.36 & 4.65 & 54.17 & 0.86 & 23.61 & 9.00 & 0.55 & 6.64 & 11.45 \\
\hline & & Mean & 0.00 & 0.05 & 0.00 & 0.00 & 0.24 & 0.00 & 0.00 & 0.00 & 11.31 & 2.78 & 0.01 & 2.69 & 1.47 & 1.44 & 47.04 & 0.39 & 19.01 & 6.28 & 0.07 & 2.14 & 5.64 \\
\hline & & SD & 0.00 & 0.10 & 0.00 & 0.00 & 0.19 & 0.00 & 0.00 & 0.00 & 0.47 & 1.34 & 0.03 & 0.43 & 0.11 & 0.31 & 2.64 & 0.34 & 3.10 & 2.62 & 0.14 & 0.34 & 1.63 \\
\hline \multirow[t]{4}{*}{ III } & & Minimum & 0.00 & 0.00 & 0.00 & 0.00 & 0.00 & 0.00 & 0.00 & 0.00 & 3.10 & 0.23 & 0.22 & 0.00 & 3.43 & 0.14 & 37.90 & 0.00 & 12.43 & 0.00 & 0.00 & 0.00 & 2.68 \\
\hline & & Maximum & 0.00 & 0.16 & 0.34 & 0.00 & 0.32 & 0.00 & 0.00 & 0.18 & 5.62 & 0.66 & 0.63 & 0.26 & 11.00 & 4.99 & 60.49 & 0.40 & 34.32 & 0.95 & 1.58 & 2.41 & 11.57 \\
\hline & & Mean & 0.00 & 0.05 & 0.08 & 0.00 & 0.09 & 0.00 & 0.00 & 0.02 & 4.46 & 0.41 & 0.41 & 0.08 & 7.68 & 2.35 & 51.39 & 0.11 & 24.00 & 0.52 & 0.52 & 0.37 & 7.63 \\
\hline & & SD & 0.00 & 0.07 & 0.13 & 0.00 & 0.14 & 0.00 & 0.00 & 0.07 & 0.91 & 0.12 & 0.12 & 0.10 & 2.15 & 1.24 & 6.66 & 0.15 & 6.72 & 0.42 & 0.69 & 0.80 & 2.62 \\
\hline
\end{tabular}

${ }^{a}$ The means are means from two or three determinations for each strain.

${ }^{b}$ The number before the colon indicates the number of carbon atoms in the chain, and the number after the colon indicates the number of double bonds. $\mathrm{C}_{10: 0}$, decanoate; $C_{12: 0}$, dodecanoate; $C_{13: 0}$, tridecanoate; $C_{13: 1}$, cis-9-tridecanoate; $C_{14: 0}$, tetradecanoate; $C_{14: 1}$, cis-9-tetradecanoate; $C_{15: 0}$, pentadecanoate; $C_{15: 1}$, cis-9-pentadecanoate; $\mathrm{C}_{16: 0}$, hexadecanoate; $\mathrm{C}_{16: 1}$, cis-9-hexadecenoate; $\mathrm{C}_{17: 0}$, heptadecanoate; cyc $\mathrm{C}_{17: 0}$, cis-9,10-methylenehexadecanoate; $\mathrm{C}_{18: 0}$, octadecenoate; $\mathrm{C}_{18: 1}$, trans-9-octadecenoate; $\mathrm{C}_{18: 1}{ }^{*}$, cis-9-octadecenoate (cis-vaccinic acid); $\mathrm{C}_{19: 0}$, nonadecanoate; cyc $\mathrm{C}_{19: 0}$, cis-9,10-methyleneoctadecanoate; 3-OH $\mathrm{C}_{14: 0}, 3$-hydroxytetradecanoate; $\mathrm{X} 1, \mathrm{X} 2$, and $\mathrm{X} 3$, unknown peaks.

or root nodules on $S$. rostrata with TAL 674 (data not shown), confirming our previous hypothesis that the culture of TAL 674 that we used is not an Azorhizobium culture and probably is a contaminant or is mislabeled (16).

The 16S rRNA data placed all of the photosynthetic rhizobia in the Bradyrhizobium group (Fig. 4), but none of the newly studied strains had a sequence identical to the sequence of BTAi 1, which was the only photosynthetic rhizobium studied previously (40). Three strains of photosynthetic rhizobia (IRBG2, IRBG 230, and ORS 322) had identical sequences, even though they were isolated from different host species or at distant geographical locations. The Bradyrhizobium cluster is very tight; even when Rhodopseudomonas palustris and the photosynthetic rhizobia are included, the most dissimilar members of the cluster are separated by just 12 nucleotide substitutions in the $16 \mathrm{~S}$ rRNA segment which we studied. For this reason, it is not possible to be very precise about relationships within the cluster, but the branches of the 16S rRNA dendrogram (Fig. 4) correlate remarkably well with groups defined by other criteria and in particular with the groups of soybean bradyrhizobia defined by DNA homology data (8). Five branches of bradyrhizobia can be discerned in Fig. 4. The first branch is the most distantly related and contains $B$. elkanii
USDA 31 and USDA $76^{\mathrm{T}}$ (i.e., homology group II of the soybean bradyrhizobia [14]) together with IRBG 274, a nonphotosynthetic symbiont of Aeschynomene afraspera. The second branch contains ATCC 1032, which is the type strain of Bradyrhizobium japonicum, and USDA 59, both of which are included in homology group I of soybean symbionts. This branch also contains the nonsymbiotic phototroph Rhodopseudomonas palustris (two strains that have the same sequence) and Crotalaria symbiont IRBG 309. The third branch contains soybean symbionts belonging to homology group Ia (USDA 110 and RCR 3407), as well as a Lotus bradyrhizobium (NZP 2257) and BTAi 1, which is of course both symbiotic and photosynthetic. The last two branches also contain photosynthetic rhizobia; one branch contains IRBG 231 by itself, and the other branch contains three strains that have identical sequences (IRBG 2, IRBG 230, and ORS 322).

The phylogenetic conclusions described above were based on comparisons of a 264-base segment of the 16S rRNA gene, which is a relatively short sequence for this purpose, although it includes some of the most informative parts of the gene. Nevertheless, conclusions based on data from this segment agree very well with other data and have generally been confirmed by data for more extensive 16S rRNA sequences

FIG. 3. Aligned sequences of parts of the 16S rRNAs of strains IRBG 2, IRBG 230, IRBG 231, IRBG 274, IRBG 309, and ORS 322. The corresponding sequences of BTAi 1 and the type strains of $B$. japonicum (4a) and B. elkanii are included for comparison. The blank spaces indicate positions where the sequences are identical to the consensus sequence (shown at the top), the dots indicate positions where there are alignment gaps, and $\mathrm{N}$ indicates an undetermined base. The nucleotides at positions 221 to 264 are identical in all of the sequences. 


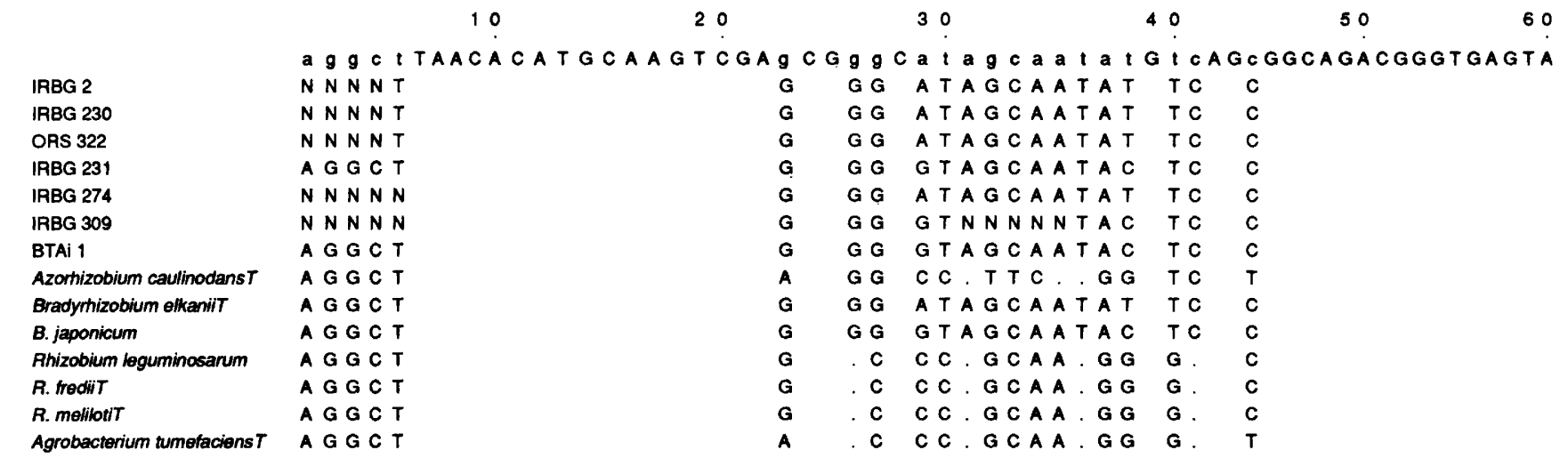

\section{IRBG 2 \\ IABG 230 \\ ORS 322 \\ IRBG 231 \\ IRBG 274 \\ IRBG 309}

BTAI 1

Azorhizobium caulinodans T

Bradyhizobium elkaniiT

B. japonicum

Rhizobium loguminosarum

A. tredit

R. melilotit

Agrobacterium tumefaciens T

IRBG 2

IRBG 230

OAS 322

IRBG 231

IRBG 274

IRBG 309

BTAi 1

Azornizobium caulinodans $T$ Bradymizobium elkaniiT

B. japonicum

Rhizobium leguminoserum

R. troditT

R. melibotiT

Agrobacterium tumefaciens T
70 80

90

100

110

120

ACGCGTGGGAACgTaCCITIIg TICGGAACA a C C TGGGAAACTIGIgCTAATACCGgA

\begin{tabular}{|c|c|c|c|}
\hline G & A & $T$ & $\mathbf{T} \mathbf{T} \mathbf{G} \mathbf{G}$ \\
\hline G & A & $T$ & $T T G G$ \\
\hline$G$ & A & $T$ & $\mathbf{T} \mathbf{T} \mathbf{G} \mathbf{G}$ \\
\hline G & A & $T$ & $\mathbf{T} \mathbf{T} \mathbf{G}$ \\
\hline G & A & $T$ & $\mathbf{T} \mathbf{T G} \mathbf{G}$ \\
\hline & A & $T$ & $\mathbf{T} \mathbf{T} \mathbf{G} \mathbf{G}$ \\
\hline & A & $T$ & $T \mathbf{T} \mathbf{G}$ \\
\hline & $\mathbf{G}$ & $c$ & T C A G \\
\hline & A & $T$ & $\mathbf{T} \mathbf{T} \mathbf{G} \mathbf{G}$ \\
\hline & A & $T$ & $\mathbf{T} \mathbf{T} \mathbf{G}$ \\
\hline & A & c & T GA C \\
\hline & $\mathbf{A}$ & c & T T T C \\
\hline & A & C & $T T T C$ \\
\hline & A & $\mathbf{G}$ & $G C C C$ \\
\hline
\end{tabular}

130

140

C A ACA

c A ACA

C A A C A

C A ACA

C A T GA

C A ACA

C A ACA

TA C CA

C A TGA

C A ACA

$T A$ GCA

$T$ A GCA

TA GCA

$T$ G TCC

$$
150
$$

160

TGT GC

TGTGC

TGTGC

TGTGC

$T C A G C$

TGTGC

TGTGC

TGGGC

TCAGC

TGTGC

TGTGC

TGTGC

TGTGC

GGAAT

$$
170
$$

180

Ta a c c C t t a c GgGAAAGATTIATCG c g a A GAT g gCCCGCGTCIGATTAGCTAGTT

\begin{tabular}{|c|c|}
\hline & \\
\hline 1 & C C G A \\
\hline$T$ & $C$ C G A \\
\hline$T$ & $C \subset G A$ \\
\hline $\mathrm{T}$ & $C \subset G A$ \\
\hline$T$ & $C C G A$ \\
\hline$T$ & $C \subset G A$ \\
\hline G & $C T G A$ \\
\hline$T$ & $C \subset G A$ \\
\hline$T$ & $C \subset G A$ \\
\hline$T$ & $G T C A$ \\
\hline $\mathbf{T}$ & $G G A A$ \\
\hline$T$ & $G G A A$ \\
\hline$T$ & G G G T \\
\hline
\end{tabular}

$\begin{array}{llll}\text { AA } & \text { C } & \text { TTAC } & \text { G } \\ \text { AA } & \text { C } & \text { TTAC } & \text { G } \\ \text { AA } & \text { C } & \text { TTAC } & \text { G } \\ \text { AA } & \text { C } & \text { TTAC } & \text { G } \\ \text { AA } & \text { C } & \text { TTAC } & \text { G } \\ \text { AA } & \text { C } & \text { TTAC } & \text { G } \\ \text { AA } & \text { C } & \text { TTAC } & \text { G } \\ \text { AC } & \text { T } & \text { GAAA } & \text { A } \\ \text { AA } & \text { C } & \text { TTAC } & \text { G } \\ \text { AA } & \text { C } & \text { TTAC } & \text { G } \\ \text { GT } & \text { T } & \text { TTCG } & \text { A } \\ \text { GA } & \text { C } & \text { TTCG } & \text { G } \\ \text { GA } & \text { C } & \text { TTCG } & \text { G } \\ \text { AC } & \text { C } & \text { TACG } & \text { G }\end{array}$

C G

C $\mathbf{G}$

C G

C G

C G

C G

C G

C $\mathbf{G}$

C G

C $G$

G A

GA

G A

G A

\section{T}

C T

C T

$C T$

CT

C T

C T

$C T$

CT

C T

T G

$T G$

$T G$
190
200
210
220

IRBG 2

IRBG 230

ORS 322

IRBG 231

IRBG 274

IRBG 309

BTAj 1

Azorhizobium caulinodansT

Bradymizobium olkanilT

B. japonicum

Rhizobium kguminosarum

R. froditT

R. melilotit

Agrobacterium tumefaciens T

\begin{tabular}{|c|c|c|c|}
\hline $\mathbf{G} \mathbf{G}$ & $T$ & C C & $A G$ \\
\hline G G & $T$ & c c & A G \\
\hline G G & $T$ & c c & $A G$ \\
\hline G G & $T$ & C C & $A G$ \\
\hline G A & $\mathbf{T}$ & T C & A G \\
\hline $\mathbf{G} \mathbf{A}$ & $T$ & $T C$ & A G \\
\hline$A G$ & $T$ & C T & $A G$ \\
\hline GA & $\mathbf{T}$ & $T C$ & A G \\
\hline G A & $\mathbf{T}$ & $\mathbf{T C}$ & $A G$ \\
\hline G A & $T$ & $T C$ & $A G$ \\
\hline G G & A & C T & C A \\
\hline G G & A & C T & $C A$ \\
\hline G G & A & C T & $C A$ \\
\hline G G & A & C T & $C A$ \\
\hline
\end{tabular}

GGTggGGTAAIGGCCCACCAAGGCGACGATCagTAGCTGG 


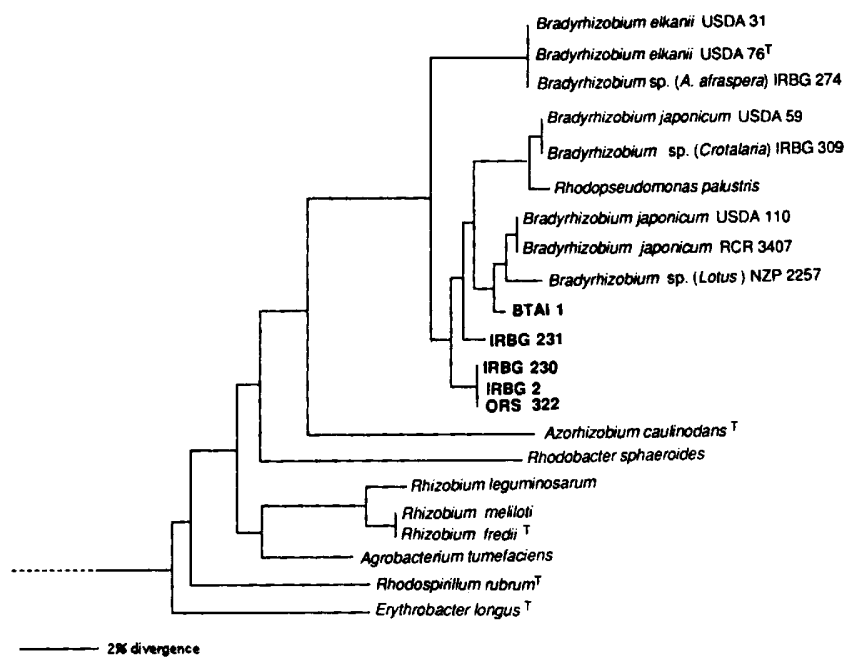

FIG. 4. Phylogenetic tree derived from 16S rRNA gene fragment data. The tree was constructed by using the neighbor-joining method and the distance matrix data in Table 4 . Bar $=2 \%$ sequence divergence.

when such data are available. In particular, the close relationship between Rhodopseudomonas palustris and B. japonicum was clear when longer sequences were obtained for two of the photosynthetic rhizobia considered in this study (BTAi 1 and IRBG 230) and for a strain isolated from Aeschynomene aspera (MKAa2), and these data confirmed the close relationship with the genus Bradyrhizobium (36a). There is not sufficient variation in the 264-base segment to permit reliable conclusions concerning the root or exact branching order within this group of organisms, but in fact the members of the group are so closely related that even almost full-length $16 \mathrm{~S}$ rRNA sequences are not conclusive (unpublished data from bootstrap analyses of previously published data). In any case, our major conclusion is very robust and is that all of the photosynthetic rhizobia examined in this study are very closely related to the genus Bradyrhizobium and distantly related to the genera Rhizobium and Azorhizobium; this finding is clearly inconsistent with the clustering data derived from numerical taxonomy (16).

Overall, the agreement between the results of the FAME analysis and the 16S rRNA sequence analysis was excellent. Not only were the genera Bradyrhizobium, Rhizobium, and Azorhizobium readily separated, but some of the relationships within these genera were also supported by both lines of evidence. Within the genus Bradyrhizobium, B. elkanii and IRBG 274 form a very distinct subgroup, and most of the photosynthetic bradyrhizobia also form a coherent subgroup; the exception is BTAi 1 , which is more closely related to $B$. japonicum and other nonphotosynthetic bradyrhizobia. The results of both techniques also indicate that Rhizobium meliloti and Rhizobium fredii are very similar and that Rhizobium leguminosarum is much more closely related to these taxa than Rhizobium galegae is. It is widely accepted that rRNA sequences provide some of the most reliable evidence available for determining phylogenetic relationships (35), but it is always valuable to have independent support. The close agreement between the conclusions from the 16S rRNA sequence and FAME profile analyses shows that fatty acids not only are a useful tool for determining the taxonomic positions of bacteria (12), including members of the family Rhizobiaceae $(20,38)$, but also provide a good guide to phylogenetic relationships (1, 21-23).

Although the FAME and 16S rRNA data described above are in good agreement in indicating that the photosynthetic rhizobia belong in the genus Bradyrhizobium, perhaps as one or more new species, there is an apparent conflict between this conclusion and results obtained from numerical taxonomy. In a separate study of many of the same strains, in which a large number of phenotypic characteristics were used, we found that the photosynthetic rhizobia belong to a phenon that is separate from the genera Bradyrhizobium, Azorhizobium, and Rhizobium (16). A dendrogram derived by mean linkage cluster analysis showed that the phenon containing the photosynthetic rhizobia is linked to the genera Azorhizobium and Rhizobium. However, this does not necessarily mean that the photosynthetic rhizobia are more closely related to the genera Azorhizobium and Rhizobium than to the genus Bradyrhizobium. The cluster analysis of phenotypic data was not explicitly designed to reveal evolutionary relationships, although in the absence of other information taxonomists often have used such analyses to define taxonomic groups. The problems encountered with the use of phenotypic data for this purpose include the lack of reliability of properties that are variable or unstable in culture, the fact that properties may evolve in parallel or convergently in different lineages in response to similar selection pressures, the absence of any objective method for weighting different characters, and the different results produced by alternative clustering algorithms. Phenotypic clustering neither equates directly with phylogenetic grouping (29) nor takes into account the origin of the resemblance or the rate of change of resemblance (ancestor-descendant relationship). This is not the first time that a disparity between phylogenetic and phenotypic data has been found in studies of the rhizobia. As determined by phenetic analysis, the fast-growing symbionts of soybeans were sufficiently distinct from the previously described Rhizobium species that a new genus, Sinorhizobium, seemed necessary and appropriate (3), but in terms of rRNA data and certain other characteristics (including the FAME profiles reported in this paper), the same isolates are so similar to Rhizobium meliloti that they can scarcely be distinguished (9).

The current practice in bacterial systematics is to take a "polyphasic" approach, that is, to put together evidence of a variety of different kinds into a composite assessment of relationships. However, it has been recognized that evidence from sequence comparisons is particularly powerful and is likely to provide the best guide to evolutionary relationships in cases where different lines of evidence point to different conclusions $(7,25,32)$. On balance, therefore, it seems likely that the photosynthetic rhizobia do belong in the Bradyrhizobium cluster, forming a distinct group within it (with the exception of BTAi 1). This group probably deserves species status, but it would be valuable to have DNA-DNA hybridization data before a formal proposal is made.

We are still left with some interesting general questions posed by the apparent conflict between sequence and FAME data on the one hand and numerical taxonomy on the other. Should this example, and the comparable case of the genus Sinorhizobium, persuade us that numerical taxonomy based on phenotypic characteristics does not provide reliable evidence concerning evolutionary relationships? Or should it instead remind us that sequence data do not by themselves tell us everything (or even anything) that is interesting about the biology of organisms? Both views are probably true. 


\section{ACKNOWLEDGMENTS}

We thank Maggie Knox for training R.B.S. in PCR and DNA sequencing techniques, Helen Downer for help with the University of Wisconsin Genetics Computer Group, software, and the John Innes Institute (United Kingdom) for supplies and facilities. Reference rhizobia were provided by the NifTAL Project at Paia, Hawaii, and Bernard Dreyfus provided Azorhizobium caulinodans ORS 571.

\section{REFERENCES}

1. Bhat, U. R., R. W. Carlson, M. Busch, and H. Mayer. 1991. Distribution and phylogenetic significance of 27-hydroxyoctanoic acid in lipopolysaccharides from bacteria belonging to the alpha-2 subgroups of Proteobacteria. Int. J. Syst. Bacteriol. 41:213217.

2. Brosius, J., M. L. Palmer, P. J. Kennedy, and H. F. Noller. 1978. Complete sequence of a 16S ribosomal gene from Escherichia coli. Proc. Natl. Acad. Sci. USA 75:4801-4805.

3. Chen, W. X., G. H. Yan, and J. L. Li. 1988. Numerical taxonomic study of fast-growing soybean rhizobia and a proposal that Rhizobium fredii be assigned to Sinorhizobium gen. nov. Int. J. Syst. Bacteriol. 38:392-397.

4. Devereux, J. P., P. Haeberli, and O. Smithies. 1984. A comprehensive set of sequence analysis programs for the VAX. Nucleic Acids Res. 12:387-395.

4a.Downer, H. L., and J. P. W. Young. Unpublished data.

5. Dreyfus, B., J. L. Garcia, and M. Gillis. 1988. Characterization of Azorhizobium caulinodans gen. nov., sp. nov., a stem-nodulating nitrogen-fixing bacterium isolated from Sesbania rostrata. Int. J. Syst. Bacteriol. 38:89-98.

6. Eaglesham, A. R. J., J. M. Ellis, W. R. Evans, D. E. Fleishman, M. Hungria, and R. W. F. Hardy. 1990. The first photosynthetic $\mathrm{N}_{2}$-fixing Rhizobium: characteristics, p. 805-811. In P. M. Gresshoff, L. E. Roth, G. Stacey, and W. L. Newton (ed.), Nitrogen fixation: achievements and objectives. Chapman and Hall, Ltd., London.

7. Graham, P. H., M. J. Sadowsky, H. H. Keyser, Y. M. Barnet, R. S. Bradley, J. E. Cooper, D. J. De Ley, B. D. W. Jarvis, E. B. Roslycky, B. W. Strijdom, and J. P. W. Young. 1991. Proposed minimal standards for the description of new genera and species of root- and stem-nodulating bacteria. Int. J. Syst. Bacteriol. 41:582587.

8. Hollis, A. B., W. E. Kloos, and G. H. Elkan. 1981. DNA:DNA hybridization studies of Rhizobium japonicum and related Rhizobiaceae. J. Gen. Microbiol. 123:215-222.

9. Jarvis, B. D. W., H. L. Downer, and J. P. W. Young. 1992. Phylogeny of fast-growing soybean-nodulating rhizobia supports synonymy of Sinorhizobium and Rhizobium and assignment to Rhizobium fredii. Int. J. Syst. Bacteriol. 42:93-96.

10. Jarvis, B. D. W., M. Gillis, and J. De Ley. 1986. Intra- and intergeneric similarities between ribosomal RNA cistrons of Rhizobium and Bradyrhizobium species and some related bacteria. Int. Syst. Bacteriol. 36:129-138.

11. Jukes, T. H., and C. R. Cantor. 1969. Evolution in protein molecules, p. 21-123. In H. N. Munro (ed.). Mammalian protein metabolism. Academic Press, New York.

12. Kaneda, T. 1991. Iso- and anteiso-fatty acids in bacteria: biosynthesis, function, and taxonomic significance. Microbiol. Rev. 55: 288-302.

13. Kuykendall, L. D., M. A. Roy, J. J. O'Neill, and T. E. Devine. 1988. Fatty acids, antibiotic resistance, and deoxyribonucleic acid homology groups of Bradyrhizobium japonicum. Int. J. Syst. Bacteriol. 38:358-361.

14. Kuykendall, L. D., B. Saxena, T. E. Devine, and S. E. Udell. 1992. Genetic diversity in Bradyrhizobium japonicum Jordan 1982 and a proposal for Bradyrhizobium elkanii sp. nov. Can. J. Microbiol. 38:501-503.

15. Ladha, J. K., R. P. Pareek, R. B. So, and M. Becker. 1990. Stem nodule symbiosis and its unusual properties, p. 633-640. In P. M. Gresshoff, L. E. Roth, G. Stacey, and W. L. Newton (ed.), Nitrogen fixation: achievements and objectives. Chapman and Hall, New York.
16. Ladha, J. K., and R. B. So. Numerical taxonomy of photosynthetic rhizobia nodulating Aeschynomene species. Int. J. Syst. Bacteriol., in press.

17. Lindström, K. 1989. Rhizobium galegae, a new species of legume root nodule bacteria. Int. J. Syst. Bacteriol. 39:365-367.

18. Lindström, K., B. D. W. Jarvis, P. E. Lindström, and J. J. Patel. 1983. DNA homology, phage typing, and cross-inoculation studies of rhizobia infecting Galega species. Can. J. Microbiol. 29:781789.

19. Lindström, K., and S. Lehtomaki. 1988. Metabolic properties, maximum growth, temperature and phage sensitivity of Rhizobium sp. (Galega) compared with other fast-growing rhizobia. FEMS Microbiol. Lett. 50:277-287.

20. MacKenzie, S. L., M. S. Lapp, and J. J. Child. 1978. Fatty acid composition of Rhizobium spp. Can. J. Microbiol. 25:68-74.

21. Mayer, H. 1984. Significance of lipopolysaccharide structure for questions of taxonomy and phylogenetical relatedness of gramnegative bacteria, p. 71-83. In E. Haber (ed.), The cell membrane. Plenum Press, New York.

22. Mayer, H., H. Masoud, T. Urbanik-Sypneiwska, and J. Weckesser. 1989. Lipid A composition and phylogeny of gram-negative bacteria. Bull Jpn. Fed. Cult. Collect. 5:19-25.

23. Moreno, E., E. Stackebrandt, M. Dorsch, J. Wolters, M. Busch, and H. Mayer. 1990. Brucella abortus 16S rRNA and lipid A reveal phylogenetic relationship with Proteobacteria of the alpha-2 subdivision. J. Bacteriol. 172:3569-3576.

24. Moss, C. W. 1990. The use of cellular fatty acids for identification of microorganisms, p. 59-69. In A. Fox et al. (ed.), Current perspectives in microbiology. Plenum Press, New York.

25. Murray, R. G. E., D. J. Brenner, R. R. Colwell, P. De Vos, M. Goodfellow, P. A. D. Grimont, N. Pfennig, E. Stackebrandt, and G. A. Zavarzin. 1990. Report of the Ad Hoc Committee on Approaches to Taxonomy within the Proteobacteria. Int. J. Syst. Bacteriol. 40:213-215.

26. Sadowsky, M. J., B. B. Bohlool, and H. H. Keyser. 1987. Serological relatedness of Rhizobium fredii to other rhizobia and to the bradyrhizobia. Appl. Environ. Microbiol. 53:1785-1789.

27. Saitou, N., and M. Nei. 1987. The neighbor-joining method: a new method for reconstructing phylogenetic trees. Mol. Biol. Evol. 4:406-425.

28. Sneath, P. H. A., and R. R. Sokal. 1973. Numerical taxonomy. Freeman, San Francisco.

29. Sokal, R. R., and P. H. A. Sneath. 1963. Numerical taxonomy. Freeman, London.

30. Watanabe, I., P. A. Roger, J. K. Ladha, and C. van Hove. 1992. Biofertilizer germplasm collections at IRRI. The International Rice Research Institute, Manila, Philippines.

31. Watanabe, I., R. B. So, J. K. Ladha, Y. Fujimura, and H. Kuraishi. 1987. A new nitrogen fixing species of pseudomonad: Pseudomonas diazotrophicus $\mathrm{sp}$. nov. isolated from the root of wetland rice. Can. J. Microbiol. 33:670-678.

32. Wayne, L. G., D. J. Brenner, R. R. Colwell, P. A. D. Grimont, O. Kandler, M. I. Krichevsky, L. H. Moore, W. E. C. Moore, R. G. E. Murray, E. Stackebrandt, M. P. Starr, and H. G. Trüper. 1987. Report of the Ad Hoc Committee on Reconciliation of Approaches to Bacterial Systematics. Int. J. Syst. Bacteriol. 37:463464.

33. Wedlock, D. N., and B. D. W. Jarvis. 1986. DNA homologies between Rhizobium fredii, rhizobia that nodulate Galega sp., and other Rhizobium and Bradyrhizobium species. Int. J. Syst. Bacteriol. 36:550-558.

34. Willems, A., and M. D. Collins. 1993. Phylogenetic analysis of rhizobia and agrobacteria based on 16S rRNA gene sequences. Int. J. Syst. Bacteriol. 43:305-313.

35. Woese, C. R. 1987. Bacterial evolution. Microbiol. Rev. 51:221271.

36. Woese, C. R., E. Stackebrandt, W. G. Weisburg, B. J. Paster, M. T. Madigan, V. J. Fowler, C. M. Hahn, P. Blanz, R. Gupta, K. H. Nealson, and G. E. Fox. 1984. The phylogeny of purple bacteria: the alpha-subdivision. Syst. Appl. Microbiol. 5:327-336.

36a.Wong, F. Y. K., E. Stackebrandt, J. K. Ladha, D. E. Fleischman, R. A. Date, and J. A. Fuerst. Unpublished data.

37. Yanagi, M., and K. Yamasato. 1993. Phylogenetic analysis of the 
family Rhizobiaceae and related bacteria by sequencing of $16 \mathrm{~S}$ rRNA gene using PCR and DNA sequencer. FEMS Microbiol. Lett. 107:115-120.

38. Yokota, A. 1989. Taxonomic significance of cellular fatty acid composition in Rhizobium, Bradyrhizobium and Agrobacterium species. Inst. Ferment. Res. Commun. (Osaka) 14:25-39.

39. Young, J. P. W. 1992. Phylogenetic classification of nitrogen-fixing organisms, p. 43-86. In G. Stacey, R. H. Burris, and H. J. Evans (ed.), Biological nitrogen fixation. Chapman and Hall, New York.

40. Young, J. P. W., H. L. Downer, and B. D. Eardly. 1991. Phylogeny of the phototrophic rhizobium strain BTAi1 by polymerase chain reaction-based sequencing of a $16 \mathrm{~S}$ rRNA gene segment. J. Bacteriol. 173:2271-2277. 